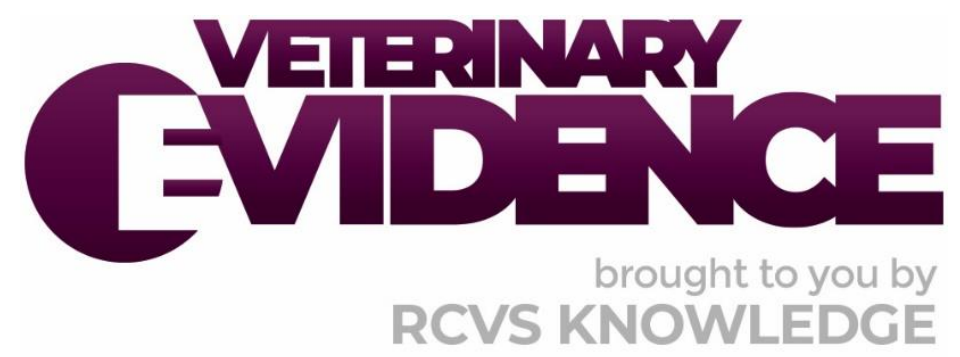

\title{
In Dogs Bitten by the European Adder (Vipera Berus), Do Corticosteroids and Supportive Treatment Improve Clinical Outcome Compared to Supportive Treatment
} Alone?

\section{A Knowledge Summary by}

Hannah Harjen BVetMed, MRCVS ${ }^{1 *}$

\footnotetext{
${ }^{1}$ Faculty of Veterinary Medicine, Department of Companion Animal Clinical Sciences Norwegian University of Life Sciences (NMBU)

Corresponding Author (hannah.harjen@nmbu.no)
}

ISSN: 2396-9776

Published: 08 Aug 2018

in: Vol 3, Issue 3

DOI: http://dx.doi.org/10.18849/ve.v3i3.178

Reviewed by: Nicola Bates (BSc, MSc, MA) and Tiffany Blackett

(BSc (Brunel), BSc (Open), MSc, MA) 
KNOWLEDGE SUMMARY

\section{PICO question}

In dogs bitten by the European adder (Vipera berus), do corticosteroids and supportive treatment improve clinical outcome compared to supportive treatment alone?

\section{Clinical bottom line}

- There is currently insufficient strength of evidence to either support or reject the use of glucocorticoids in dogs bitten by the European adder (Vipera berus) and further controlled trials are needed to fully answer this question.

- Glucocorticoids may be indicated in cases of adverse reaction to antivenom treatment although there is not enough evidence to conclude whether there is a benefit to prophylactic administration prior to antivenom treatment.

\section{Clinical scenario}

Many dogs are bitten by the European adder (Vipera berus) between April and October each year. Treatment has often included administration of glucocorticoids and, in some countries, owners have traditionally carried glucocorticoid tablets to administer as an emergency treatment prior to seeking veterinary help (Lund et al., 2013, Turkovic et al., 2015).

Through their anti-inflammatory effects, glucocorticoids may reduce the pain and inflammation associated with snakebites in dogs as well as treating adverse reactions following antivenom administration (Lund et al., 2013, Armentano and Schaer, 2011). Potential disadvantages of glucocorticoid administration in these patients may include dose-dependent immunosuppression and increased catabolism (Leisewitz et al., 2004). The potential for delay in seeking veterinary help when owners administer glucocorticoids as an emergency treatment is also a concern.

A client comes into your practice and requests prednisolone tablets to administer to their dog in case of a bite by the European adder (Vipera berus). You wish to know whether there is any evidence that giving glucocorticoids will improve clinical outcome in dogs bitten by the European adder, compared to supportive treatment alone.

\section{The evidence}

One double-blinded randomised placebo-controlled trial (Brandeker et al., 2015) and two prospective case series (Lervik et al., 2010, Lund et al., 2013) were identified as relating to this question. The studies by Lund et al. (2013) and Lervik et al. (2010) had a relatively low sample size ( $n=54$ and $n=53$, respectively). The largest sample size studied was 75 (Brandeker et al., 2015). Sample size was reduced by loss to follow-up in all three studies.

Two studies were identified (Brandeker et al., 2015, Lervik et al., 2010) as specifically considering the effect of glucocorticoids on outcome in dogs bitten by the European adder. No studies of time to recovery in relation to glucocorticoid treatment were found. The study by Brandeker et al. (2015) was a double-blinded randomised controlled trial and thus ranks highly in term of evidence hierarchy. It does have some limitations which somewhat reduce its value and applicability to general first opinion practice. Findings in the prospective case series by Lervik et al. (2010) are in accordance with those of Brandeker et al. (2015); however, the evidence is weaker due to study design. Lund et al. (2013) focused on adverse effects of antivenom in a prospective case series. This study is not directly related to the PICO question and is of lower evidentiary value but was accepted after full review, based on the inclusion of dogs treated with glucocorticoids. 
No studies found a beneficial effect of corticosteroid treatment in these patients apart from in one case of adverse reaction to antivenom (Lund et al., 2013). No detrimental effect of corticosteroid administration was identified by the current evidence.

Two retrospective case series by Turkovic et al. (2015) and Sutton et al. (2011) provided the lowest ranking evidence considered. These were of limited use and provided statements relating to the use of glucocorticoids, which appeared to be based on conjecture, or findings relating to other snake species. These two studies are therefore not included in the evidence summary.

\section{Summary of the evidence}

\begin{tabular}{|c|c|}
\hline \multicolumn{2}{|l|}{ Brandeker et al. (2015) } \\
\hline Population: & $\begin{array}{l}\text { Dogs bitten by Vipera berus between April } 2011 \text { and September } 2012 \text { and } \\
\text { presenting to Evidensia Södra Djursjukhuset or Evidensia } \\
\text { Specialistdjursjukhuset Strömsholm, within } 24 \text { hours of the bite. } \\
\text { Inclusion criteria: } \\
\text { - reported snake bite (observed snake bite, fang marks or a high } \\
\text { and } \quad \text { suspicion of snake bite) } \\
\text { - clinical signs typical of envenomation (local swelling and pain) } \\
\text { Exclusion criteria: } \\
\text { - pregnancy } \\
\text { - vaccination within last two weeks } \\
\text { - renal disease } \\
\text { - diabetes mellitus } \\
\text { - hyperadrenocorticism } \\
\text { - on-going treatment with glucocorticoids for pre-existing medical } \\
\text { - conditions } \\
\text { - treatment with non-steroidal anti-inflammatory drugs (NSAIDS) }\end{array}$ \\
\hline Sample size: & $n=75$ (hospital one $n=51$, hospital two $n=24$ ) \\
\hline Intervention details: & $\begin{array}{l}\text { - Two treatment groups: PRED }(n=38) \text { and PLACEBO }(n=37) \\
\text { One subcutaneous injection of } 1 \mathrm{mg} / \mathrm{kg} \text { prednisolone (PRED) OR } \\
0.1 \mathrm{ml} / \mathrm{kg} 0.9 \% \mathrm{NaCl}(\mathrm{PLACEBO}) \text { at admission, following envenomation } \\
\text { by the European adder } \\
\text { - Supportive treatment: all dogs received IV fluids (type not specified) } \\
\text { and opioid analgesics (methadone or buprenorphine - dose rates not } \\
\text { specified) } \\
\text { - Double blinded: the intervention treatment was administered by a } \\
\text { technician }\end{array}$ \\
\hline Study design: & Randomised controlled trial (double-blinded) \\
\hline Outcomes studied: & $\begin{array}{l}\text { Data collected at three timepoints: } \\
\begin{array}{l}\text { - day one }=\text { admission } \\
\text { - day two }=24 \mathrm{~h}+/-5 \mathrm{~h} \text { (hospital one) or } 24 \mathrm{~h}+/-12 \mathrm{~h} \text { (hospital two) }\end{array}\end{array}$ \\
\hline
\end{tabular}




\begin{tabular}{|c|c|}
\hline & $\begin{array}{l}\text { - day three }=10-28 \text { days } \\
\text { Primary variables: } \\
\text { - Mental status } \\
\text { - Oedema: measured and then classified as absent, mild, moderate or } \\
\text { severe } \\
\text { Secondary variables: } \\
\text { - Appetite (subjective) } \\
\text { - Vomiting } \\
\text { - Diarrhea } \\
\text { - Cardiac arrhythmia } \\
\text { - Death } \\
\text { - Blood analysis: C-reactive protein (CRP), cardiac troponin I (cTnl), } \\
\text { haematology variables, prothrombin time (PT) }\end{array}$ \\
\hline $\begin{array}{r}\text { Main findings: } \\
\text { (relevant to PICO } \\
\text { question): }\end{array}$ & $\begin{array}{l}\text { No significant difference was found between PRED and PLACEBO groups in } \\
\text { terms of: } \\
\text { - } \text { mental status } \\
\text { - } \text { extent of oedema } \\
\text { - } \text { vomiting } \\
\text { - cardiac arrhythmia } \\
\text { - diarrhea } \\
\text { - } \text { CRP, prothrombin time, total leucocyte count } \\
\text { Statistically significant differences found between PRED and PLACEBO groups: } \\
\text { - Higher monocyte count (within reference range) in PRED group on day } \\
\text { - } \text { two } \\
\text { Higher cTnl concentration (within normal reference range) in PRED } \\
\text { group on day one, no difference on day two }\end{array}$ \\
\hline Limitations: & $\begin{array}{l}\text { - The exclusion of dogs who were deemed to require antivenom after } \\
\text { inclusion in the study is a potential source of bias. These dogs may have } \\
\text { been more severely affected } \\
\text { - The randomisation method is not sufficiently described and hence it is } \\
\text { unclear whether the study can truly be classified as a randomised } \\
\text { controlled trial. A few of the outcome variables were recorded } \\
\text { restrospectively, leading to questions of the blinding process } \\
\text { - Variation in treatment following administration of prednisolone or } \\
\text { placebo leading to a confounding effect of a non-standardised } \\
\text { intervention protocol } \\
\text { - } 21 \text { dogs were lost to follow-up thus reducing the sample size. It is not } \\
\text { - Specified which treatment group these originated from } \\
\text { - Lack of standardisation of measurement of outcome parameters such } \\
\text { as oedema and mental status, and multiple observers, leads to a lack of } \\
\text { objectivity when comparing the two treatment groups } \\
\text { - Presence or absence of cardiac arrhythmia not based on ECG and may } \\
\text { therefore be under-estimated }\end{array}$ \\
\hline
\end{tabular}




\begin{tabular}{|l|l|}
\hline - & $\begin{array}{l}\text { Due to the referral setting, dogs with mild and only local signs may } \\
\text { have been under-represented thus creating a bias towards more } \\
\text { severely affected dogs }\end{array}$ \\
- & Wider range of time from bite to presentation in the prednisolone \\
treated group (1-24 hours) versus the placebo group (0.5-11.5 hours) \\
and non-standardised timing of steroid administration and data \\
collection in relation to time of bite \\
A sample size calculation is not described in the methods
\end{tabular}

\begin{tabular}{|c|c|}
\hline \multicolumn{2}{|l|}{ Lervik et al. (2010) } \\
\hline Population: & $\begin{array}{l}\text { Dogs bitten by Vipera berus between April and August } 2006 \text { and presenting to } \\
\text { Södra Djursjukhuset in Stockholm or the University Animal Hospital in Uppsala, } \\
\text { within seven hours of the bite. } \\
\text { Inclusion criteria: } \\
\text { - Strong suspicion of viper bite (bite witnessed or viper seen close to the } \\
\text { dog) } \\
\text { and/or } \\
\text { - clinical signs of a viper bite (lethargy, swelling) } \\
\text { Exclusion criteria: } \\
\text { - ongoing treatment with glucocorticoids for reasons other than the } \\
\text { - viper bite } \\
\text { known history of liver disease }\end{array}$ \\
\hline Sample size: & $\mathrm{n}=53$ ( from two hospitals - individual numbers not stated) \\
\hline Intervention details: & 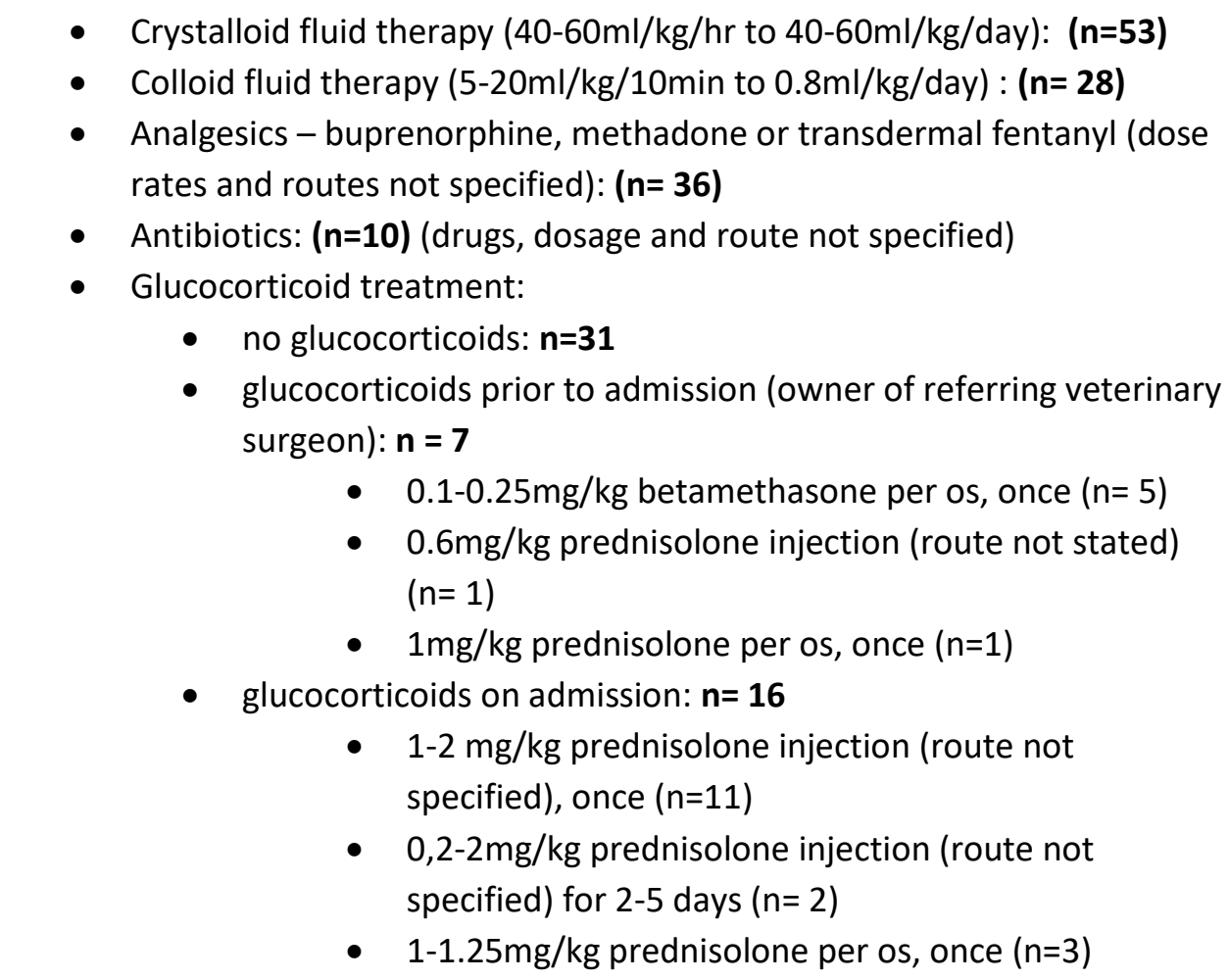 \\
\hline Study design: & Prospective case series \\
\hline Outcomes studied: & $\begin{array}{l}\text { Data collected at four timepoints: } \\
\text { - Arrival }(n=53)\end{array}$ \\
\hline
\end{tabular}




\begin{tabular}{|c|c|}
\hline & $\begin{array}{l}\text { - } 24 \text { hours }(\mathrm{n}=52) \\
\text { - } \text { Day 4-10 ( } \mathrm{n}=46) \\
\text { Variables recorded: } \\
\text { - } \text { Degree of swelling - mild, moderate or severe } \\
\text { - } \text { Mental status - alert, slightly, moderately or severely depressed } \\
\text { - Serum biochemistry ( } \mathrm{n}=34) \text { : } \\
\text { - } \text { alanine aminotransferase (ALT) } \\
\text { - alkaline phosphatase (ALP) } \\
\text { - gile acids } \\
\text { - glutamate dehydrogenase (GLDH) } \\
\text { - creatine kinase (CK) } \\
\text { - Presence/absence of cardiac arrhythmia on auscultation } \\
\text { - ECG characterisation of arrhythmias detected on auscultation }(\mathrm{n}=5)\end{array}$ \\
\hline $\begin{array}{r}\text { Main findings: } \\
\text { (relevant to PICO } \\
\text { question): }\end{array}$ & $\begin{array}{l}\text { - No significant differences were found between the glucocorticoid } \\
\text { treated group and non-glucocorticoid treated group in terms of: } \\
\text { - Degree of swelling } \\
\text { - Mental status } \\
\text { glucocorticoid treated group compared to the untreated group } \\
\text { - Treatment with glucocorticoids did not have any clear positive or } \\
\text { negative effect on clinical signs and mortality }\end{array}$ \\
\hline Limitations: & $\begin{array}{l}\text { - The distribution of cases between the two hospitals is not described } \\
\text { and is therefore a source of potential bias due to possible differences in } \\
\text { treatment and assessment of patients } \\
\text { - Several observers and non-standardised measurement of subjective } \\
\text { variables such as degree of oedema lead to a lack of objectivity when } \\
\text { comparing the glucocorticoid-treated and untreated groups } \\
\text { - Confounding effect of non-standardised treatment protocols is not } \\
\text { accounted for } \\
\text { - } 20 \text { dogs lost to follow up and serum analysis not included for } 19 \text { dogs, } \\
\text { thus decreasing the sample size } \\
\text { - Different numbers of samples at the different timepoints; missing data } \\
\text { - Oedema measurement not standardised in some cases (17\%) - this } \\
\text { outcomes was measured after steroid administration } \\
\text { - inclusion of these individuals is not provided. It is unclear why a dog } \\
\text { with hyperadrenocorticism was included when dogs with pre-existing } \\
\text { liver disease or receiving long-term steroids were excluded } \\
\text { Bias due to dogs receiving glucocorticoids being likely to have shown } \\
\text { more severe clinical effects following the adder bite } \\
\text { Discussion states that no difference was found in recovery time }\end{array}$ \\
\hline
\end{tabular}




\begin{tabular}{|l|l|}
\hline between the two groups although this measurement is not clearly \\
described or stated in materials \& methods or results \\
Lack of statistical analysis; poor reporting of statistical analysis makes it \\
difficult to fully assess the results
\end{tabular}

\begin{tabular}{|c|c|}
\hline \multicolumn{2}{|l|}{ Lund et al. (2013) } \\
\hline Population: & $\begin{array}{l}\text { Dogs presenting to private small animal clinics and the Department of } \\
\text { Companion Animal Clinical Sciences at the Norwegian School of } \\
\text { Veterinary Medicine in Oslo between } 2006 \text { and 2009, with clinical signs } \\
\text { consistent with Vipera berus envenomation. } \\
\text { Inclusion criteria: } \\
\text { - Snake or bite witnessed by the owner } \\
\text { or - Wounds consistent with fang marks found by veterinary } \\
\text { - surgeon } \\
\text { Exclusion criteria: } \\
\text { - Lack of clinical signs consistent with envenomation } \\
\text { - Uncertainty with regards to whether clinical signs were caused } \\
\text { by an adder bite }\end{array}$ \\
\hline Sample size: & $n=54$ \\
\hline Intervention details: & 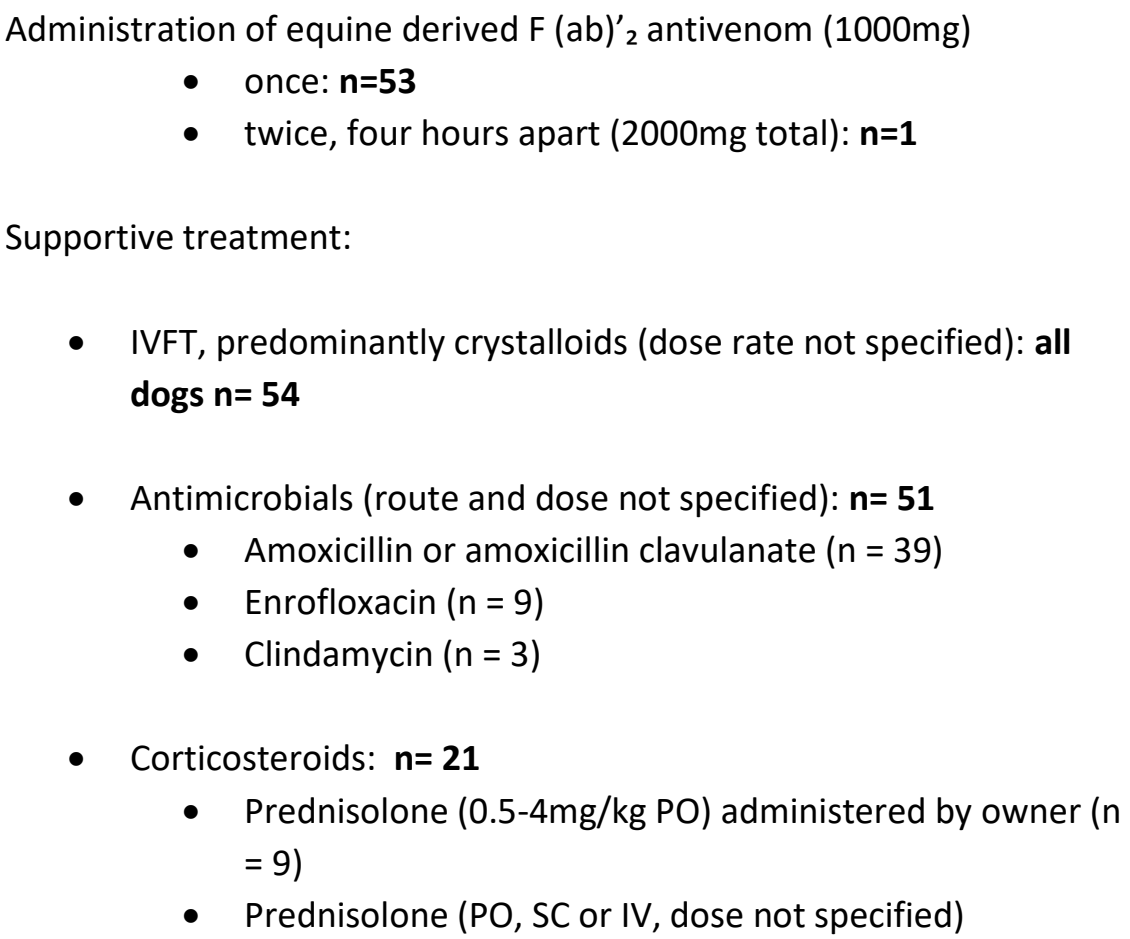 \\
\hline
\end{tabular}




\begin{tabular}{|c|c|}
\hline & $\begin{array}{l}\text { administered by veterinary surgeon }(n=7) \\
\text { Dexamethasone (PO, SC or IV, dose not specified) } \\
\text { administered by veterinary surgeon }(n=6) \\
\text { - Hydrocortisone (PO, SC or IV, dose not specified) } \\
\text { administered by veterinary surgeon }(n=1) \\
\text { - Non-specified steroid }(n=1) \\
\text { Control group: } \\
\text { - Dogs bitten by Vipera berus but not administered antivenom }\end{array}$ \\
\hline Study design: & Prospective case Series \\
\hline Outcomes studied: & 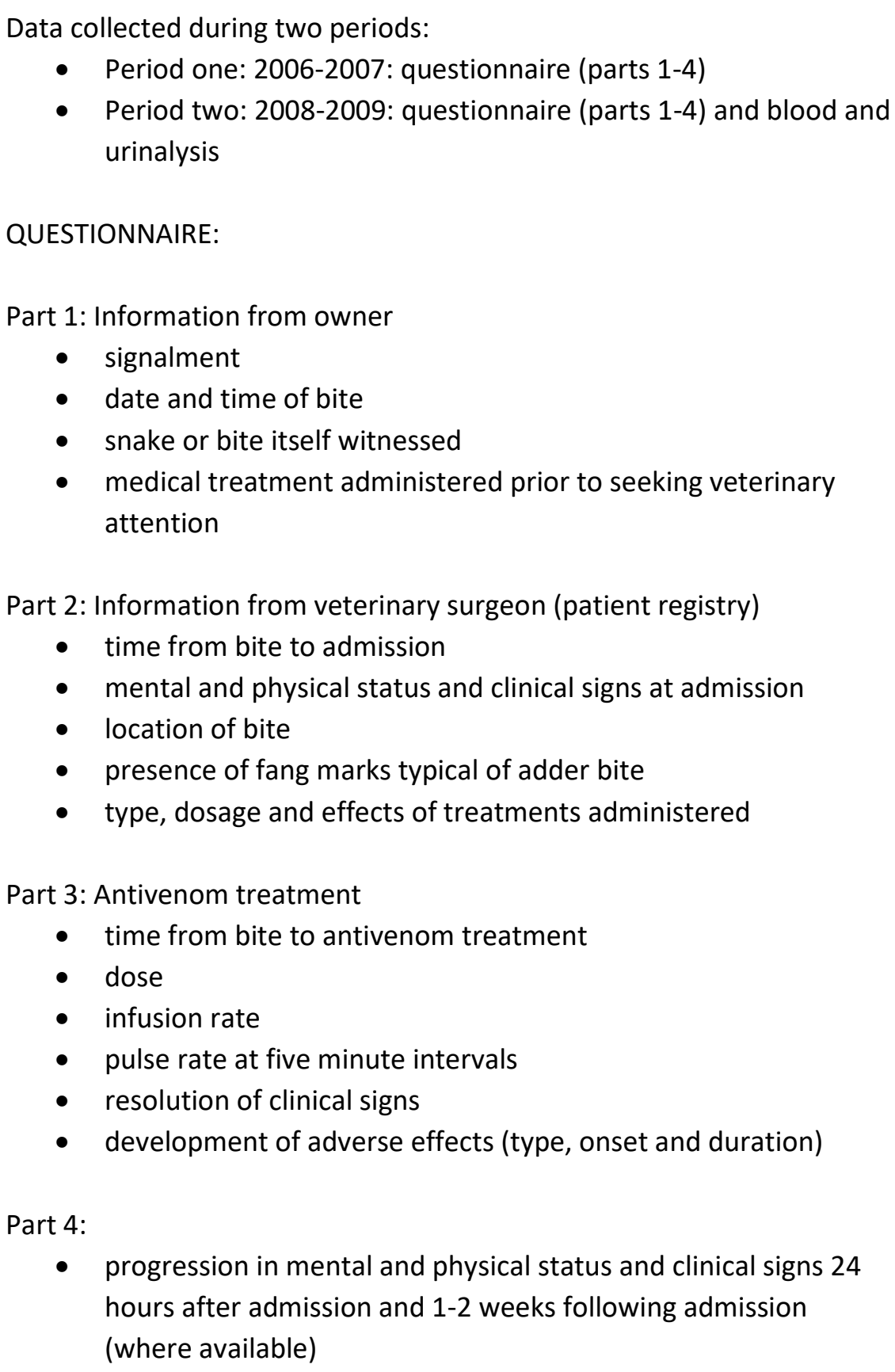 \\
\hline
\end{tabular}




\begin{tabular}{|c|c|}
\hline & $\begin{array}{l}\text { BLOOD AND URINALYSIS: } \\
\text { - blood and urine samples collected at admission and 1-2 weeks } \\
\text { following treatment (where possible) } \\
\text { - } \quad \text { serum globulin and albumin } \\
\text { - } \text { urine protein }\end{array}$ \\
\hline $\begin{array}{l}\text { Main findings: } \\
\text { (relevant to PICO question): }\end{array}$ & $\begin{array}{l}\text { - Non-self-limiting facial swelling secondary to antivenom } \\
\text { administration responded to corticosteroid therapy in one dog } \\
\text { - Two dogs developed adverse reactions to antivenom despite } \\
\text { prior glucocorticoid treatment } \\
\text { - It was uncertain whether glucocorticoids prevented the } \\
\text { development of adverse reactions in the remaining } 20 \text { dogs } \\
\text { who received both glucocorticoids and antivenom }\end{array}$ \\
\hline Limitations: & $\begin{array}{l}\text { - Many observers and non-standardised treatment protocols } \\
\text { resulted in a number of confounders } \\
\text { - A control group is used only for blood and urinalysis and is not } \\
\text { adequately described } \\
\text { Proportions of patients from referral versus first opinion } \\
\text { practice are not documented, leading to a potential bias in } \\
\text { severity of clinical symptoms and timing of treatments } \\
\text { - The intervention is not standardised: need for antivenom } \\
\text { treatment was made subjectively by a number of different } \\
\text { veterinary surgeons. Dogs receiving antivenom may therefore } \\
\text { have been more severely affected than the control group } \\
\text { - Subjectivity of a number of the outcome variables and multiple } \\
\text { observers results in a lack of objectivity and comparability of } \\
\text { results } \\
\text { - Response rate to questionnaires is not reported. It is possible } \\
\text { that questionnaires at the university were more likely to be } \\
\text { responded to as the investigator was on site to chase up. There } \\
\text { is therefore a possible further bias towards those dogs } \\
\text { presenting to the referral center and thereby potentially more } \\
\text { severely affected } \\
\text { Lack of randomisation or matching of study and control groups }\end{array}$ \\
\hline
\end{tabular}

\section{Appraisal, application and reflection}

Evidence pertaining to this PICO question is limited and of variable evidentiary value. The quality of evidence available is generally limited by bias due to non-standardised treatment and intervention protocols as well as potential bias towards more severely affected dogs and a reliance on measurement of subjective outcome variables. Confounders such as the amount of venom per bite, non-homogenous venom in different adder populations, location of bite, body size of dog and time to presentation are present in all three studies and are difficult to control for in a clinical research setting. Routine investigations are relatively insensitive for detecting cardiac arrhythmia and renal injury and, as such, these potential markers of clinical outcome are difficult to fully assess in these studies (Palviainen et al., 2013, Vestberg et al., 2017).These factors limit the conclusions that can be drawn from these studies regarding effects of glucocorticoids in envenomated patients.

The study by Brandeker et al. (2015) reports no difference in mental status, extent of oedema, appetite, 
vomiting and diarrhea, cardiac arrhythmias, C-reactive protein (CRP), prothrombin time (PT), total leucocyte count or duration of hospitalisation between prednisolone and placebo-treated groups. These findings are relevant to answering this PICO question since many of these parameters could influence clinical outcome. This study ranks highly in terms of evidence hierarchy. However, there are a number of limitations which do influence the quality of the evidence produced and its applicability in general small animal practice. The randomised and double-blinded status of this study is questioned by a lack of adequate description of the methods used and the fact that one of the outcome parameters was recorded retrospectively. There is a bias towards earlier treatment in the placebo group as demonstrated by a wider distribution of time from bite to presentation in the prednisolone-treated group compared to the placebo group. Non-standardisation of the treatment protocol beyond the initial prednisolone or placebo injection and of treatment within the prednisolone-treated group also creates problems with comparability. Dogs requiring antivenom were excluded. Whilst this eliminates this confounding factor, another source of bias is created since the patients requiring antivenom may have been more severely affected. Furthermore, information regarding the proportional group allocation of dogs excluded once they were deemed to require antivenom is not provided. Many of the outcome parameters are subjective variables with multiple observers involved, again leading to objectivity problems when comparing the two groups. A sample size calculation is not described and statistical analysis does not appear to account for confounders. Twenty-one dogs were lost to follow up and the exact proportions of cases lost to follow-up between the two groups is not described. Milder cases may have been under-represented in this study and as such the applicability to first opinion practice is limited.

Lervik et al. (2010) also compared glucocorticoidtreated dogs to non-glucocorticoid treated dogs. This study can be considered of some use in answering this PICO. Findings of no significant difference in degree of oedema and mental status between glucocorticoid-treated and non-glucocorticoid treated untreated dogs are consistent with those of Brandeker et al. (2015). This study does however suffer similar limitations to the study by Brandeker et al. (2015), in addition to its lower ranking evidentiary status due to design. Bias due to lack of randomisation, non-standardised intervention and treatments as well as the confounding effects of concurrent disease make comparisons difficult. Sample size calculation is lacking and statistical analysis is poorly reported, thus hindering interpretation of significance. There is a greater bias towards most severely affected dogs in this study since the decision to administer glucocorticoids was based on the individual clinician's opinion. The authors discuss the fact that no difference was found in mortality rates or time to recovery between the two groups. However, this should be interpreted with caution given the fact that these parameters are not defined in the materials and methods or reported in the results. The mortality rate of dogs bitten by the European adder is reported to be between 3\% and 4.8\% (Sutton et al., 2011, Kängström, 1989). It is therefore possible that the lack of observed difference found in this study is due to small sample size rather than lack of effect. The study by Lund et al. (2013) is at first glance not related to the PICO question. However, on more thorough review, it does provide some useful insights and thoughts to base further research on despite not being able to provide direct conclusive evidence specifically regarding glucocorticoid treatment and outcome.

Approximately $39 \%$ of dogs in this study received steroids; two dogs developed adverse reactions to antivenom despite prior treatment with steroids. Corticosteroid administration was of benefit to one dog in this study during an adverse reaction to antivenom treatment but did not prevent adverse reaction to antivenom in two dogs. A further 19 dogs received corticosteroids in this study and did not suffer an adverse reaction to subsequent antivenom treatment. Causation cannot be established but it does suggest that further studies regarding glucocorticoid use and adverse reactions following antivenom administration would be useful. This study also suffers a number of limitations including a lack of matching of the control group, subjective outcome measures and non-standardised treatments. Confounding effects of antivenom treatment and time of glucocorticoid administration in relation to antivenom treatment are also present, which limit the study's value.

The studies by Brandeker et al. (2015) and Lervik et al. (2010) refer to the finding of a negative association between steroid administration and survival in dogs bitten by Vipera palaestinae (Segev et al., 2004). Whilst this finding is interesting, viper venom varies between species and individuals (Malina et al., 2017, White, 2005) and findings from this study are subject to bias due to more severely affected dogs being more likely to be administered steroids. The study by Segev et al. (2004) also fails to specify route of corticosteroid administration, dose rates and timing of administration in relation to bite. Therefore, statements basing 
contraindications for steroid administration on the treatment of Vipera berus envenomation, on this evidence, should be interpreted with caution. Controlled, randomised studies involving injecting venom in canine patients could help to answer this question more fully but are very unlikely to obtain ethical approval. In summary the main findings of this review are that extent of oedema, mental status and duration of hospitalisation are not significantly different in Vipera berus envenomated dogs treated with glucocorticoids compared to dogs receiving supportive treatment alone. Hence, there is currently no evidence that glucocorticoids improve clinical outcome in these patients. However, these findings are largely from one randomised controlled trial subject to some limitations and largely apply to dogs presenting with more severe symptoms. Little evidence exists regarding the use of glucocorticoids in dogs with mild symptoms after envenomation. Further studies are needed to fully answer the question of whether glucocorticoids should be indicated or not in these patients. Whilst there is also currently no conclusive evidence to suggest that steroids are contraindicated in dogs bitten by the European adder, clinicians should consider that administration of glucocorticoids by an owner may delay them seeking veterinary help. Given the suggestion by the current evidence that glucocorticoids are unlikely to have a large beneficial effect, and the possibility of consequent delays in seeking expert help, steroids cannot currently be recommended as an emergency treatment for owners to administer or as a necessary part of a clinical treatment protocol, other than possibly in cases of adverse reaction to antivenom.

These findings are in accordance with the human literature. Studies in humans have failed to demonstrate improvement in clinical outcome following glucocorticoid administration in snake-envenomated patients other than in cases of adverse reaction to antivenom (Karlson-Stiber et al., 2006, Boels et al., 2012). Glucocorticoid administration following Vipera berus envenomation in humans is limited to cases of acute or delayed hypersensitivity to antivenom treatment.

Further high-quality evidence through randomised controlled trials with greater standardisation of treatment protocols would be helpful in answering this question fully. It would also be of use to study dogs presenting to first opinion practice. Studies comparing time to presentation between dogs administered glucocorticoids by the owner and dogs who do not receive glucocorticoids at point of bite, could also be helpful in building a more convincing body of evidence, for or against the use of glucocorticoids in this scenario.

\section{Methodology Section}

\begin{tabular}{|c|c|}
\hline \multicolumn{2}{|l|}{ Search Strategy } \\
\hline $\begin{array}{r}\text { Databases searched and dates } \\
\text { covered: }\end{array}$ & $\begin{array}{l}\text { - } \quad \text { CAB Abstracts on OVID Platform } 1973 \text { - Week } 202018 \\
\text { - Web of Science (clarivate analytics) } 1945 \text {-2018 } \\
\text { - } \quad \text { Medline on OVID platform } 1902 \text { - present } \\
\text { - Scopus (Elsevier) } 1960 \text { - present }\end{array}$ \\
\hline Search terms: & 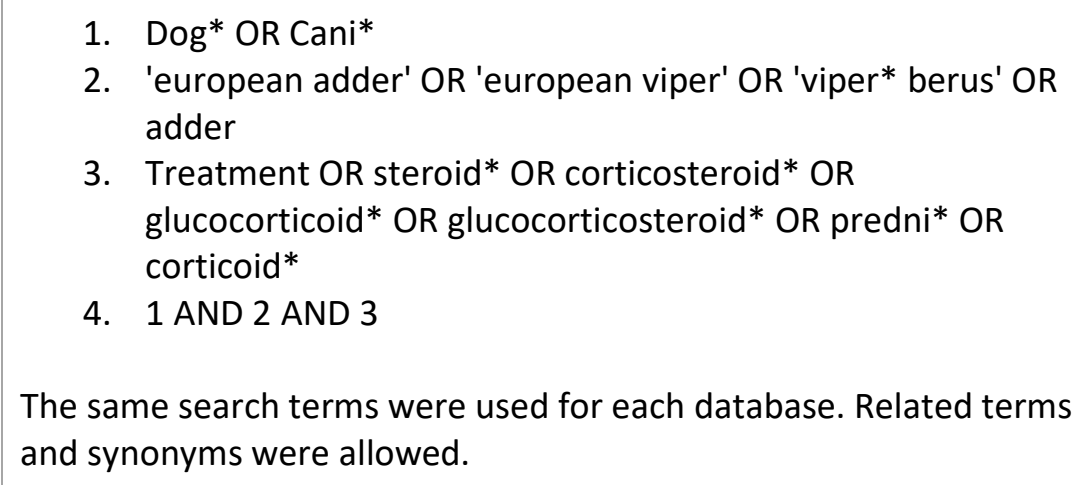 \\
\hline Dates searches performed: & 27.05 .2018 \\
\hline
\end{tabular}




\begin{tabular}{|c|c|}
\hline \multicolumn{2}{|l|}{ Exclusion / Inclusion Criteria } \\
\hline Exclusion: & $\begin{array}{l}\text { - Envenomation by snake species other than Vipera berus } \\
\text { - } \quad \text { Non-english language. } \\
\text { - } \quad \text { Reviews of available treatments. }\end{array}$ \\
\hline Inclusion: & $\begin{array}{l}\text { - Studies regarding the use of glucocorticoids in canine } \\
\text { patients envenomated by Vipera berus. }\end{array}$ \\
\hline
\end{tabular}

\begin{tabular}{|c|c|c|c|c|c|c|c|c|}
\hline \multicolumn{9}{|c|}{ Search Outcome } \\
\hline Database & $\begin{array}{c}\text { Number } \\
\text { of } \\
\text { results }\end{array}$ & $\begin{array}{l}\text { Excluded } \\
\text { - non- } \\
\text { English } \\
\text { language }\end{array}$ & $\begin{array}{l}\text { Excluded - } \\
\text { did not } \\
\text { meet PICO } \\
\text { question }\end{array}$ & $\begin{array}{c}\text { Excluded - } \\
\text { conference } \\
\text { proceeding } \\
\text { or letter }\end{array}$ & $\begin{array}{c}\text { Excluded } \\
\text { - book } \\
\text { chapter }\end{array}$ & $\begin{array}{l}\text { Excluded- } \\
\text { duplicate }\end{array}$ & $\begin{array}{l}\text { Excluded - } \\
\text { after full } \\
\text { review did } \\
\text { not meet } \\
\text { PICO } \\
\text { question }\end{array}$ & $\begin{array}{c}\text { Total } \\
\text { relevant } \\
\text { papers }\end{array}$ \\
\hline $\begin{array}{l}\text { CAB } \\
\text { Abstracts }\end{array}$ & 30 & 9 & 13 & 3 & 1 & 0 & 1 & 3 \\
\hline $\begin{array}{l}\text { Web of } \\
\text { Science }\end{array}$ & 13 & 3 & 5 & 1 & 0 & 4 & 0 & 0 \\
\hline Medline & 15 & 2 & 7 & 1 & 0 & 4 & 1 & 0 \\
\hline Scopus & 3 & 0 & 1 & 0 & 0 & 2 & 0 & 0 \\
\hline \multicolumn{8}{|c|}{ Total relevant papers when duplicates removed } & 3 \\
\hline
\end{tabular}

\section{CONFLICT OF INTEREST}

The author declares no conflicts of interest.

\section{REFERENCES}

1. ARMENTANO, R. A. \& SCHAER, M. 2011. Overview and controversies in the medical management of pit

\section{Veterinary Evidence}


viper envenomation in the dog. J Vet Emerg Crit Care (San Antonio), 21, 461-70.Available from:

https://www.ncbi.nlm.nih.gov/pubmed/22316194.

2. BOELS, D., HAMEL, J. F., BRETAUDEAU DEGUIGNE, M. \& HARRY, P. 2012. European viper envenomings: Assessment of Viperfav and other symptomatic treatments. Clin Toxicol (Phila), 50, 189-96.Available from: https://www.ncbi.nlm.nih.gov/pubmed/22372786.

3. BRANDEKER, E., HILLSTROM, A., HANAS, S., HAGMAN, R. \& HOLST, B. S. 2015. The effect of a single dose of prednisolone in dogs envenomated by Vipera berus--a randomized, double-blind, placebocontrolled clinical trial. BMC Vet Res, 11, 44.Available from:

https://www.ncbi.nlm.nih.gov/pubmed/25886633.

4. KARLSON-STIBER, C., SALMONSON, H. \& PERSSON, H. 2006. A nationwide study of Vipera berus bites during one year-epidemiology and morbidity of 231 cases. Clin Toxicol (Phila), 44, 25-30.Available from: https://www.ncbi.nlm.nih.gov/pubmed/16496490.

5. KÄNGSTRÖM, L. E. 1989. Adder bite (Vipera berus) in the dog and cat. Svensk Veterinartidning, 41, 3846.

6. LEISEWITZ, A. L., BLAYLOCK, R. S., KETTNER, F., GOODHEAD, A., GODDARD, A. \& SCHOEMAN, J. P. 2004. The diagnosis and management of snakebite in dogs--a southern African perspective. J S Afr Vet Assoc, 75, 7-13.Available from: https://www.ncbi.nlm.nih.gov/pubmed/15214688.

7. LERVIK, J. B., LILLIEHOOK, I. \& FRENDIN, J. H. 2010. Clinical and biochemical changes in 53 Swedish dogs bitten by the European adder--Vipera berus. Acta Vet Scand, 52, 26. Available from:

https://www.ncbi.nlm.nih.gov/pubmed/20416040.

8. LUND, H. S., KRISTIANSEN, V., EgGERTSDOTTIR, A. V., SKANCKE, E. \& RANHEIM, B. 2013. Adverse reactions to equine-derived $\mathrm{F}\left(\mathrm{ab} \mathrm{b}^{\prime}\right) 2$-antivenin in 54 dogs envenomated by Vipera berus berus. J Vet Emerg Crit Care (San Antonio), 23, 532-7.Available from:

https://www.ncbi.nlm.nih.gov/pubmed/24102941.

9. MALINA, T., KRECSAK, L., WESTERSTROM, A., SZEMAN-NAGY, G., GYEMANT, G., M, M. H., ROWAN, E. G., HARVEY, A. L., WARRELL, D. A., PAL, B., RUSZNAK, Z. \& VASAS, G. 2017. Individual variability of venom from the European adder (Vipera berus berus) from one locality in Eastern Hungary. Toxicon, 135, 59-70.Available from: https://www.ncbi.nlm.nih.gov/pubmed/28602828.

10. PALVIAINEN, M., RAEKALLIO, M., VAINIONPAA, M., LAHTINEN, H. \& VAINIO, O. 2013. Evaluation of renal impairment in dogs after envenomation by the common European adder (Vipera berus berus). Vet J, 198, 723-4.Available from: https://www.ncbi.nlm.nih.gov/pubmed/24103867.

11. SEGEV, G., SHIPOV, A., KLEMENT, E., HARRUS, S., KASS, P. \& AROCH, I. 2004. Vipera palaestinae envenomation in 327 dogs: a retrospective cohort study and analysis of risk factors for mortality. Toxicon, 43, 691-9.Available from: https://www.ncbi.nlm.nih.gov/pubmed/15109890.

12. SUTTON, N. M., BATES, N. \& CAMPBELL, A. 2011. Canine adder bites in the UK: a retrospective study of cases reported to the Veterinary Poisons Information Service. Vet Rec, 169, 607. Available from: https://www.ncbi.nlm.nih.gov/pubmed/21868437.

13. TURKOVIC, V., TEICHMANN, S. \& DORFELT, R. 2015. European Adder bites in dogs in southern 
Germany. A retrospective study over a 6.5-year period. Tierarztl Prax Ausg K Kleintiere Heimtiere, 43, 221-30.Available from: https://www.ncbi.nlm.nih.gov/pubmed/26152480.

14. VESTBERG, A. R., TIDHOLM, A. \& LUUNGVALL, I. 2017. Twenty-four-hour ambulatory electrocardiography characterization of heart rhythm in Vipera berus-envenomed dogs. Acta Vet Scand, 59, 28.Available from: https://www.ncbi.nlm.nih.gov/pubmed/28468664.

15. WHITE, J. 2005. Snake venoms and coagulopathy. Toxicon, 45, 951-67. Available from: https://www.ncbi.nlm.nih.gov/pubmed/15922768. 


\section{EVIIDEFeE

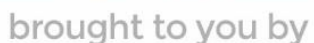 \\ RCVS KNOWLEDGE}

\section{Intellectual Property Rights}

Authors of Knowledge Summaries submitted to RCVS Knowledge for publication will retain copyright in their work, and will be required to grant RCVS Knowledge a non-exclusive license of the rights of copyright in the materials including but not limited to the right to publish, re-

publish, transmit, sell, distribute and otherwise use the materials in all languages and all media throughout the world, and to license or permit others to do so.

\section{Disclaimer}

Knowledge Summaries are a peer-reviewed article type which aims to answer a clinical question based on the best available current evidence. It does not override the responsibility

of the practitioner. Informed decisions should be made by considering such factors as individual clinical expertise and judgement along with patient's circumstances and owners' values. Knowledge Summaries are a resource to help inform and any opinions expressed within the Knowledge Summaries are the author's own and do not necessarily reflect the view of the RCVS Knowledge. Authors are responsible for the accuracy of the content. While the

Editor and Publisher believe that all content herein are in accord with current recommendations and practice at the time of publication, they accept no legal responsibility

for any errors or omissions, and make no warranty, express or implied, with respect to material contained within.

For further information please refer to our Terms of Use.

RCVS Knowledge is the independent charity associated with the Royal College of Veterinary Surgeons (RCVS). Our ambition is to become a global intermediary for evidence based veterinary knowledge by providing access to information

that is of immediate value to practicing veterinary professionals and directly contributes to evidence based clinical decision-making.

\section{https://www.veterinaryevidence.org/}

RCVS Knowledge is a registered Charity No. 230886.

Registered as a Company limited by guarantee in England and Wales No. 598443.

Registered Office: Belgravia House, 62-64 Horseferry Road, London SW1P 2AF

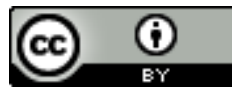

This work is licensed under a Creative Commons Attribution 4.0 International License. 